\title{
University
}

Klaus, V. and Clark, J. S. (2017) Thioether-catalysed tandem synthesis of furans and cyclic ethers or lactones. Synlett, 28(11), pp. 1358-1362.

(doi: $\underline{10.1055 / \mathrm{s}-0036-1588758)}$

This is the author's final accepted version.

There may be differences between this version and the published version. You are advised to consult the publisher's version if you wish to cite from it.

http://eprints.gla.ac.uk/141841/

Deposited on: 31 May 2017

Enlighten - Research publications by members of the University of Glasgow http://eprints.gla.ac.uk33640 


\section{Thioether-Catalysed Tandem Synthesis of Furans and Cyclic Ethers or}

Lactones

Verena Klaus

\section{J. Stephen Clark}

School of Chemistry, Joseph Black Building, University of Glasgow, University Avenue, Glasgow G12 $8 Q Q$, UK

stephen.clark@glasgow.ac.uk

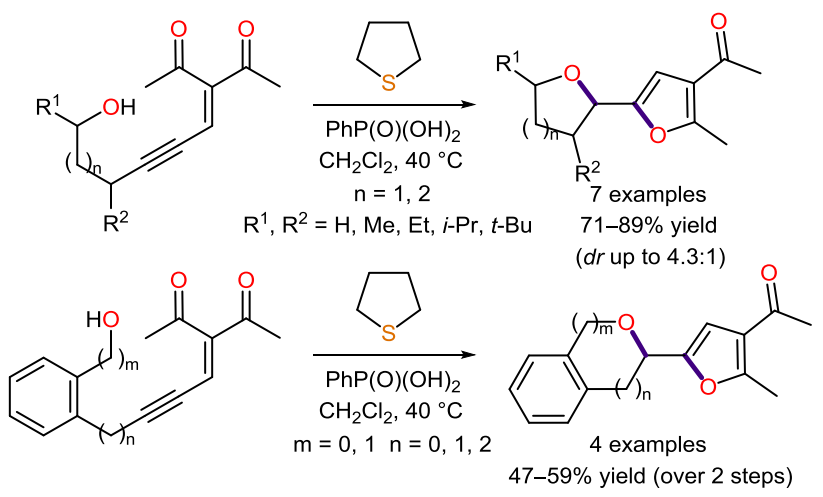

\section{Abstract}

Acyclic conjugated ynenediones tethered to an alcohol or carboxylic acid, are converted into furanylsubstituted cyclic ethers or lactones in a single step by treatment with the tetrahydrothiophene. Modest levels of diastereocontrol can be achieved in some cases where the presence of a substituent on the tether results in the creation of a second stereogenic centre upon formation of the cyclic ether or lactone.

Key words Organocatalysis, thioether, furans, lactones, cyclic ethers, tandem cyclisation 
Substituted furans are important heteroaromatic systems that occur frequently as subunits in a wide range of complex natural products, ${ }^{1}$ biologically active compounds and pharmaceutical products. ${ }^{2}$ As a consequence of their chemical, physical and biological properties, furans have found widespread use as pharmacophores in the drug discovery process. The ubiquity of furans in both natural and non-natural bioactive compounds has served as a driver for development of new synthetic methods for the rapid and efficient construction of highly functionalised furans, and considerable time has been devoted to these endeavours. ${ }^{3}$ In addition to the various classical condensation-based methods, ${ }^{4}$ a host of metal-mediated reactions using zinc, ${ }^{5}$ copper, ${ }^{6}$ palladium, ${ }^{7}$ silver $^{8}$ and gold ${ }^{9}$ complexes have been developed for the synthesis of furans.

We have recently discovered a novel organocatalytic reaction for the synthesis of di- or trisubstituted furfuryl alcohol or amine derivatives by the treatment of fully conjugated ynenones or ynenediones with tetrahydrothiophene (THT) in the presence of an external oxygen or nitrogen nucleophile (Scheme 1). ${ }^{10}$ In contrast to conventional metal-mediated or condensation-based methods, organocatalytic methods for construction of furans are rare and have been relatively unexplored. ${ }^{11}$

In our earlier work, we demonstrated that exposure of a range ynenones or ynenediones 1 to a substoichiometric amount of THT in the presence of an alcohol, carboxylic acid or sulfonamine produced the furfuryl alcohol/amine derivative 4 (Scheme 1). ${ }^{10}$ The reaction is proposed to occur by nucleophilic attack of the thioether catalyst on the alkyne to produce the zwitterionic allene 2 (Scheme 1). Cyclisation by intramolecular attack of the nucleophilic oxygen to give the furan then affords ylide 3 and subsequent proton transfer from the external acid $(\mathrm{YH})$ provides the sulfonium salt 4 . The reaction probably then proceeds through an $\mathrm{S}_{\mathrm{N}} 1$ pathway rather than a concerted $\mathrm{S}_{\mathrm{N}} 2$ process, releasing THT back into the catalytic cycle and generating an oxocarbenium ion that is trapped by the external nucleophile $\left(\mathrm{Y}^{-}\right)$to deliver the final furan product 4.

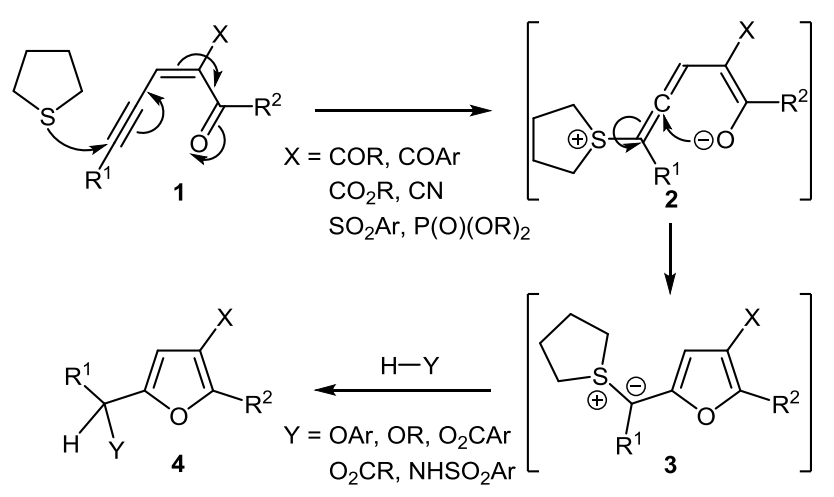

Scheme 1 Tetrahydrothiophene-catalysed synthesis of furfuryl alcohol and amine derivatives from ynenones bearing an electron-withdrawing substituent

The success of our original work prompted us to explore the application of the reaction to the synthesis of bicyclic or polycyclic natural products or synthetic bioactive compounds of the type shown in Figure 1, in which a furan is attached directly to either a cyclic ether or lactone. It was 
envisaged that in this new process, both the furan and the saturated $O$-heterocycle would be constructed by a tandem process in which two bonds and both rings would be created in a single organocatalytic reaction.

The compounds shown in Figure 1 are all natural products and/or are compounds with biological activity. The alcohol $\mathbf{5}$ was isolated from the bark of the tree Tabebuia avellanedae which is purported to have medicinal properties, ${ }^{12}$ and the chloride 6 is a synthetic C-glycoside that possesses cytotoxic activity. ${ }^{13}$ The furanyl lactones $\mathbf{7}$ and $\mathbf{8}$ were isolated from endophytic fungal strain Phomopsis sp. XZ-26 of Camptotheca acuminate and have been shown to have modest antimicrobial activity, ${ }^{14}$ and infuscolide A (9) is a clerodane-type diterpenoid natural product that was isolated from the Japanese liverwort Jungermannia infusca. ${ }^{15}$
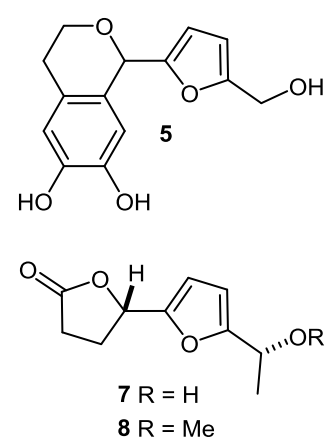<smiles>CC(=O)c1cc(C2OCC(N)C2Cl)oc1C</smiles>

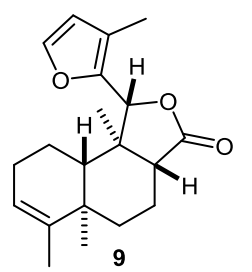

Figure 1 Examples of natural products and bioactive compounds that contain a furan attached directly to a cyclic ether or a lactone

In our original publication concerning the THT-catalysed reaction of ynenones to produce trisubstituted furfuryl alcohol derivatives, ${ }^{10}$ we had shown that the propargylic alcohol $\mathbf{1 0}$ undergoes cyclisation to give the furanyl-substituted epoxide $\mathbf{1 1}$ in good yield (Scheme 2). This result served as the precedent for exploration of a general reaction in which a tetrahydrofuran or tetrahydropyran would be formed in tandem with a furan.
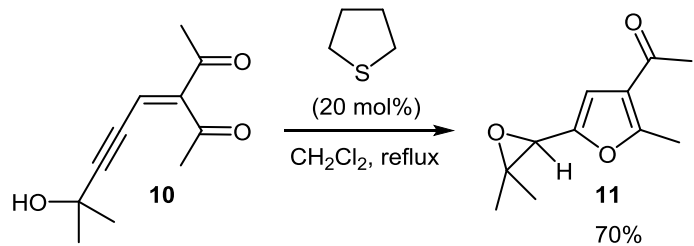

Scheme 2 Thioether-catalysed formation of an epoxyfuran from a hydroxy ynenedione

In preliminary experiments, ${ }^{16}$ we investigated the reactions of unbranched substrates in which tandem cyclisation would be expected to produce either a simple tetrahydrofuran or tetrahydropyran concomitantly with the trisubstituted furan (Scheme 3). Reactions of the acyclic ynenediones 12 and 13, which possess a tethered primary hydroxyl group, under previously established reaction conditions (10-50 mol\% THT in $\mathrm{CH}_{2} \mathrm{Cl}_{2}$, at $\left.40{ }^{\circ} \mathrm{C}\right),{ }^{10}$ afforded the expected bicyclic products $\mathbf{1 4}$ and $\mathbf{1 5}$ in excellent yield. 


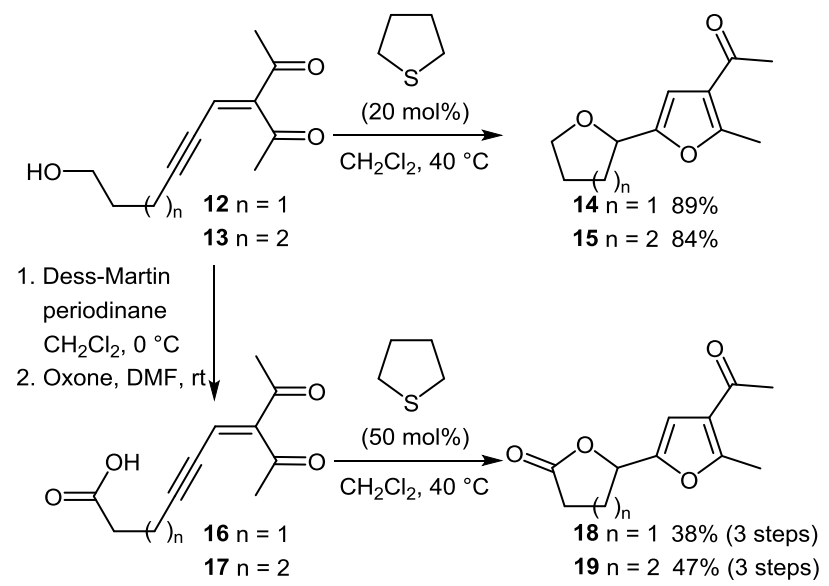

Scheme 3 Organocatalytic tandem furan and cyclic ether / lactone formation from ynenediones bearing a simple alcohol or carboxylic acid side chain

The reaction could be extended to systems containing a carboxylic acid rather than a primary hydroxyl group as the nucleophile. Cyclisation of the ynenedione substrates $\mathbf{1 6}$ and $\mathbf{1 7}$ bearing an $\omega$ carboxylic acid afforded the bicyclic products 18 and 19 , which possess a $\psi$-butyrolactone and a $\delta$ valerolactone respectively, in moderate yield.

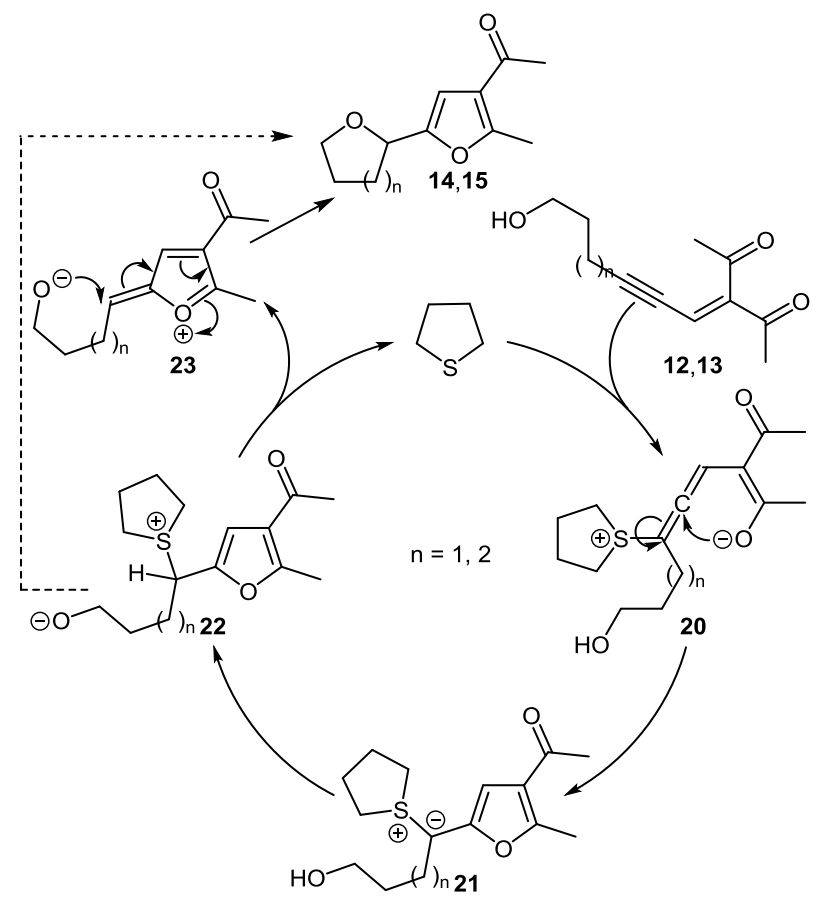

Scheme 4 Catalytic cycle for tandem furan and cyclic ether formation

Control experiments were performed and these demonstrated that THT was essential for the reaction; furan formation was not observed in the absence of this catalyst. The reaction is believed to proceed by the mechanism shown in Scheme 4 for the alcohols $\mathbf{1 2}$ and $\mathbf{1 3}$. Treatment of the substrates with THT results in nucleophilic attack of the alkyne to produce the allenyl zwitterion $\mathbf{2 0}$. Nucleophilic attack of the central carbon of the allene by the alkoxide results in cyclisation to give the furanyl sulfonium ylide 21. Proton transfer from the hydroxyl group then produces the 
zwitterion $\mathbf{2 2}$ and subsequent ejection of the thioether delivers the oxocarbenium ion $\mathbf{2 3}$, which is then trapped by the nucleophilic alkoxide to give the cyclic ethers $\mathbf{1 4}$ and $\mathbf{1 5}$ (Scheme 4).

Alternatively, it is conceivable that cyclic ether formation occurs by direct $\mathrm{S}_{\mathrm{N}} 2$ displacement of the sulfonium group in intermediate $\mathbf{2 2}$ and without the generation of the oxocarbenium ion $\mathbf{2 3}$ as an intermediate.

The use of the reaction to prepare more highly functionalised cyclic ethers, by the cyclisation of systems containing a secondary hydroxyl group or possessing a branch in the chain connecting the hydroxyl group to the ynenedione, was explored. The reactions of substrates containing a secondary hydroxyl group proved to be feasible, but $50 \mathrm{~mol} \%$ of THT was required to obtain full conversion on a reasonable timescale and it was necessary to add phenylphosphonic acid (10 mol\%) as a cocatalyst in order to effect the cyclisation reactions in a tandem fashion (Table 1). ${ }^{17}$ Cyclisation reactions of the substrates 24-28 resulted in tandem cyclisation to produce the cyclic ethers 29-33 in good yield (71-80\%), but the products were obtained as diastereomeric mixtures. ${ }^{18}$ In the case of substrates 24-26 (Table 1, entries 1-3) very low levels of diastereocontrol were obtained and there was little change in the product ratios as the size of the alkyl substituent increased (Me $\rightarrow \mathrm{Et} \rightarrow i$ Pr). Interestingly, the highest level of diastereocontrol (4.3:1) was obtained in the case where the alcohol 27, in which there is chain branching adjacent to the site of $\mathrm{C}-\mathrm{O}$ bond formation to give the tetrahydrofuran, was used as the substrate (entry 4).

Table 1 Catalytic furan formation with diastereoselective tetrahydrofuran and tetrahydropyran construction
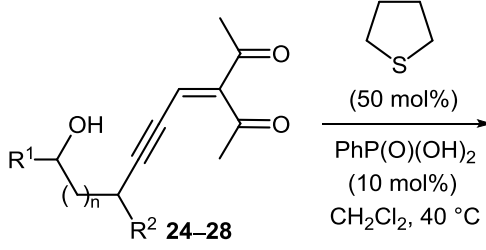

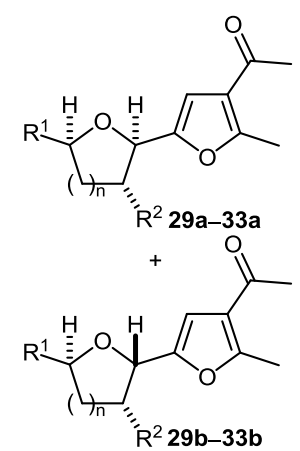

$\mathrm{R}^{2} 29 b-33 b$

\begin{tabular}{|c|c|c|c|c|c|c|c|}
\hline Entry & Substrate & $\mathrm{n}$ & $\mathrm{R}^{1}$ & $\mathrm{R}^{2}$ & Product & Yield $^{a}$ & Ratio $(\mathbf{a}: \mathbf{b})^{b}$ \\
\hline 1 & 24 & 1 & $\mathrm{Me}$ & $\mathrm{H}$ & 29 & 79 & $1: 1.2$ \\
\hline 2 & 25 & 1 & Et & $\mathrm{H}$ & 30 & 77 & 1:1.1 \\
\hline 3 & 26 & 1 & $\mathrm{i}-\mathrm{Pr}$ & $\mathrm{H}$ & 31 & 71 & $1.2: 1$ \\
\hline 4 & 27 & 1 & $\mathrm{H}$ & Me & 32 & 73 & 4.3:1 \\
\hline 5 & 28 & 2 & $t-B u$ & $\mathrm{H}$ & 33 & 80 & 2.7:1 \\
\hline
\end{tabular}

${ }^{a}$ Isolated yield after purification by chromatography.

${ }^{\mathrm{b}}$ Diastereomeric ratio determined by $1 \mathrm{H}$ NMR analysis of the crude reaction product. 
In the case of the alcohol $\mathbf{2 8}$, where the tether length between the alcohol functionality and the enyne was extended and a bulky $t$-butyl substituent was incorporated into the substrate, the reaction displayed modest selectivity for the cis product 33a over the trans product $\mathbf{3 3 b}$ (Table 1, entry 5). The stereochemical outcome of the cyclisation reaction of the alcohol $\mathbf{2 8}$ can be explained by inspection of conformers of the putative oxocarbenium intermediates $\mathbf{3 4}$, which are expected to undergo ring closure through chair-like transition states (Scheme 5). Interestingly, the configuration of the exocyclic alkene in the oxocarbenium intermediate $\mathbf{3 4}$ is not relevant because both the $E$ and $Z$ isomers of conformer $\mathbf{3 4 - C 1}$ deliver the major product $\mathbf{3 3 a}$ and both the $E$ and $Z$ isomers of conformer 34-C2 deliver the minor isomer $\mathbf{3 3 b}$. The modest preference for formation of $\mathbf{3 3 a}$ presumably reflects an early transition state for the reaction, in which there is a relatively long incipient $\mathrm{C}-\mathrm{O}$ bond, and also the fact that the trajectory of attack by the nucleophile lies orthogonal to the plane of the unsaturated ring, minimising steric interactions between the axial hydrogens and the substituents on what will become the furan.
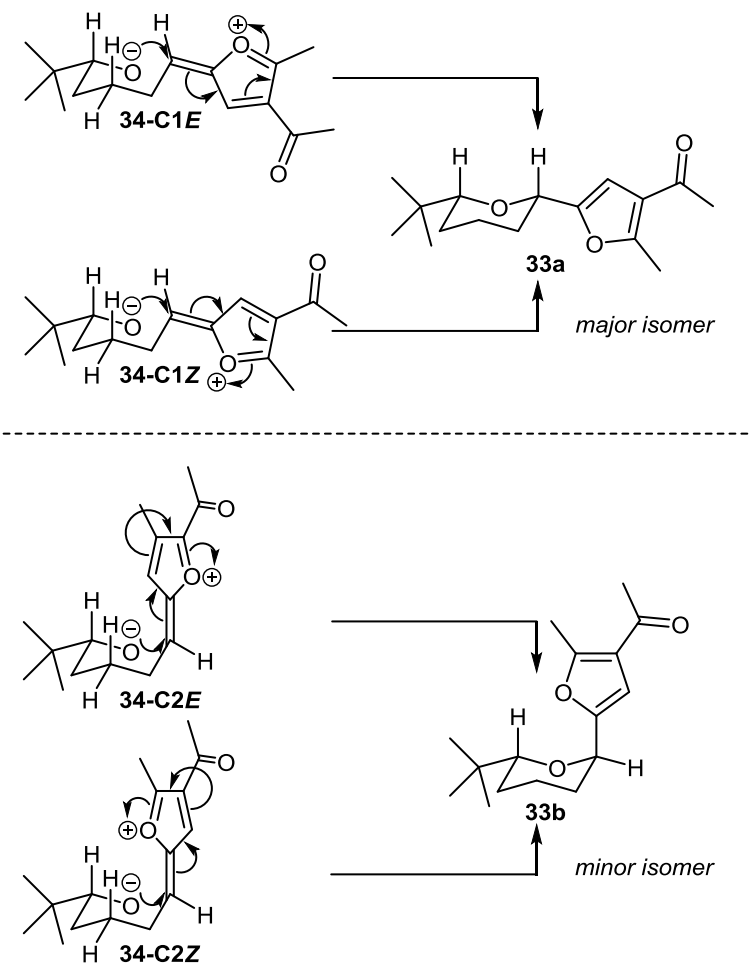

Scheme 5 Favoured conformations leading to competing transition states during the formation of diastereomeric tetrahydropyrans $\mathbf{3 3 a}$ and $\mathbf{3 3 b}$

It proved possible to use the THT-catalysed cyclisation reaction to prepare a dihydrobenzofuran or a dihydrobenzopyran in tandem with formation of the furan. The four aryl-linked substrates 35-38 were prepared and desilylated. The resulting free alcohols were then subjected to the optimised cyclisation conditions (THT plus phenylphosphonic acid) to give the dihydrobenzofurans $\mathbf{3 9}$ and $\mathbf{4 1}$ and the dihydrobenzopyrans $\mathbf{4 0}$ and $\mathbf{4 2}$ in good yield (47-59\% over two steps) (Scheme 6). 


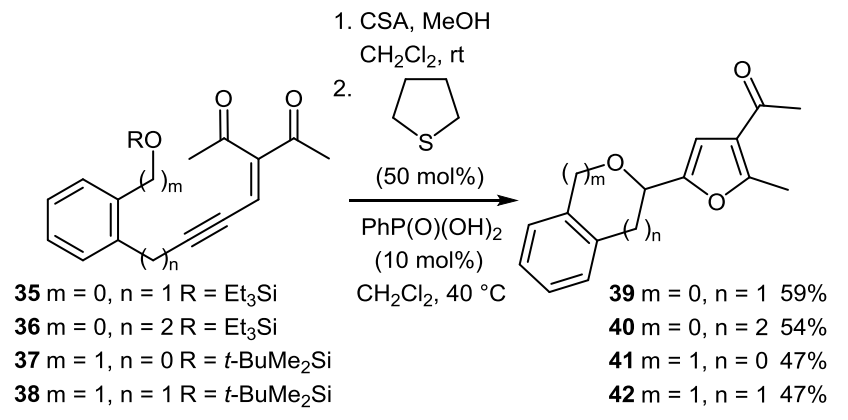

Scheme 6 Tandem synthesis of furans and dihydrobenzofurans or dihydrobenzopyrans

In summary, we have developed a new tandem organocatalysed cyclisation reaction of ynenediones, bearing a carboxylic acid or hydroxyl group tethered to the alkyne of the conjugated system, which delivers a trisubstituted furan bearing a lactone or cyclic ether. This method allows the formation of highly functionalised bicyclic systems in high yield under mild conditions, and exploits tetrahydrothiophene as an inexpensive and readily available organocatalyst. The use of phenylphosphoric acid as an acidic co-catalyst is required in order to protonate the sulfur ylide and thereby deliver high yields and minimise reaction times.

\section{Acknowledgement}

The authors gratefully acknowledge the award of a postgraduate studentship (VK) from the University of Glasgow.

\section{Supporting Information}

YES (this text will be updated with links prior to publication)

\section{Primary Data}

NO (this text will be deleted prior to publication)

\section{References and Notes}

(1) Boto, A., Alvarez, L. Heterocycles in Natural Product Synthesis, Wiley-VCH, Weinheim, 2011.

(2) Wright, R. J. Health Care Mark. 1996, 16, 24.

(3) Albrecht, Ł.; Ransborg, L. K; Jørgensen, K. A. Catal. Sci. Technol. 2012, 2, 1089.

(4) (a) Knorr, L. Chem. Ber. 1884, 17, 2863; (b) Paal C. Chem. Ber. 1884, 17, 2756; (c) Feist, F. Chem. Ber. 1902, 35, 1537; (d) Benary, E. Chem. Ber. 1911, 44, 489.

(5) (a) Vicente, R.; González, J.; Riesgo, L.; González, J.; López, L. A. Angew. Chem. Int. Ed. 2012, 51, 8063; (b) Gonzalez, J.; Gonzalez, J.; Perez-Calleja, C.; Lopez, L. A.; Vicente, R. Angew. Chem. Int. Ed. 2013, 52, 5853.

(6) (a) Barluenga, J.; Riesgo, L.; Vicente, R.; López, L. A.; Tomás, M. J. Am. Chem. Soc. 2008, 130, 13528; (b) Hu, F.; Xia, Y.; Ma, C.; Zhang, Y.; Wang, J. J. Org. Chem. 2016, 81, 3275. 
(7) (a) Oh, C. H.; Park, H. M.; Park, D. I. Org. Lett. 2007, 9, 1191; (b) Xia, Y.; Qu, S.; Xiao, Q.; Wang, Z.X.; Qu, P.; Chen, L.; Liu, Z.; Tian, L.; Huang, Z.; Zhang, Y.; Wang, J. J. Am. Chem. Soc. 2013, 135, 13502; (c) Xia, Y.; Liu, Z.; Ge, R.; Xiao, Q.; Zhang, Y.; Wang, J. Chem. Commun. 2015, 51, 11233.

(8) Chen, Z.-W.; Luo, M.-T.; Ye, D.-N.; Zhou, Z.-G.; Ye, M.; Liu, L.-X. Synth. Commun. 2014, $16,1825$.

(9) (a) Arcadi, A.; Alfonsi, M.; Chiarini, M.; Marinelli, F. J. Organomet. Chem. 2009, 694, 576; (b) Blanc, A.; Tenbrink, K.; Weibel, J.-M.; Pale, P. J. Org. Chem. 2009, 74, 5342; (c) Hoffmann, M.; Miaskiewicz, S.; Weibel, J.-M.; Pale, P.; Blanc, A. Beilstein J. Org. Chem. 2013, 9, 1774; (d) Huang, X.; Peng, B.; Luparia, M.; Gomes, L. F. R.; Veiros, L. F.; Maulide, N. Angew. Chem. Int. Ed. 2012, 51, 8886. (e) Ma, J.; Jiang, H.; Zhu, S. Org. Lett. 2014, 16, 4472.

(10) Clark, J. S.; Boyer, A.; Aimon, A.; Garcia, P. E.; Lindsay, D. M.; Symington, A. D. F.; Danoy, Y. Angew. Chem. Int. Edit. 2012, 51, 12128.

(11) (a) Kuroda, H.; Hanaki, E.; Kawakami, M. Tetrahedron Lett. 1999, 40, 3753; (b) Kuroda, H.; Hanaki, E.; Izawa, H.; Kano, M.; Itahashi, H. Tetrahedron 2004, 60, 1913. (c) Jung, C.-K.; Wang, J.-C.; Krische, M. J. J. Am. Chem. Soc. 2004, 126, 4118. (d) Albrecht, Ł.; Ransborg, L. K.; Gschwend, B.; Jørgensen, K. A. J. Am. Chem. Soc. 2010, 132, 17886.

(12) Zhang, L.; Hasegawa, I.; Tatsuno, T.; Kawabata, T.; Ohta, T.; Tadano, T. Heterocycles 2014, 89, 731.

(13) Yan, L.; Dai, G.-F.; Yang, J.-L.; Liu, F.-W.; Liu, H.-M. Bioorg. Med. Chem. Lett. 2007, $17,3454$.

(14) Lin, T.; Lin, X.; Lu, C.; Hu, Z.; Huang, W.; Huang, Y.; Shen, Y. Eur. J. Org. Chem. 2009, 2975.

(15) Nagashima, F.; Suzuki, M.; Takaoka, S.; Asakawa, Y. Chem. Pharm. Bull. 2000, 48, 1818.

(16) General procedure for the cyclisation of simple primary alcohols and carboxylic acids such as substrates 12, 13, 16 and 17: A solution of tetrahydrothiophene $(1.0 \mathrm{~mL}$ of a $0.5 \mathrm{M}$ solution in $\mathrm{CH}_{2} \mathrm{Cl}_{2}$ ) was added to solution of the ynenedione $(1 \mathrm{mmol})$ and the reaction mixture was stirred at $40{ }^{\circ} \mathrm{C}$ for $48 \mathrm{~h}$. The mixture was then concentrated under reduced pressure and the residue purified by flash column chromatography on silica gel.

1-(2-Methyl-5-tetrahydrofuranyl-3-furanyl)-ethanone (14). $\mathrm{R}_{f}=0.20$ (pet. ether-EtOAc, 5:2); ${ }^{1} \mathrm{H}$ NMR $\left(400 \mathrm{MHz}, \mathrm{CDCl}_{3}\right) \delta 6.64(1 \mathrm{H}, \mathrm{s}, \mathrm{CH}$-furan), $4.81(1 \mathrm{H}, \mathrm{dd}, \mathrm{J}=6.7,6.7 \mathrm{~Hz}, \mathrm{CHO}), 3.97-3.92(1 \mathrm{H}$, $\left.\mathrm{m}, \mathrm{CH}_{2} \mathrm{O}\right), 3.86-3.81\left(1 \mathrm{H}, \mathrm{m}, \mathrm{CH}_{2} \mathrm{O}\right), 2.53\left(3 \mathrm{H}, \mathrm{s}, \mathrm{CH}_{3} \mathrm{C}\right), 2.34\left(3 \mathrm{H}, \mathrm{s}, \mathrm{CH}_{3} \mathrm{C}=\mathrm{O}\right), 2.20-2.13(1 \mathrm{H}, \mathrm{m}$, $\left.\mathrm{CH}_{2} \mathrm{CHO}\right), 2.09-1.99\left(2 \mathrm{H}, \mathrm{m}, \mathrm{CH}_{2} \mathrm{CHO}, \mathrm{CH}_{2} \mathrm{CH}_{2} \mathrm{O}\right), 1.98-1.92\left(1 \mathrm{H}, \mathrm{m}, \mathrm{CH}_{2} \mathrm{CH}_{2} \mathrm{O}\right) ;{ }^{13} \mathrm{C} \mathrm{NMR}(101 \mathrm{MHz}$, $\left.\mathrm{CDCl}_{3}\right) \delta 194.1,158.3,153.0,121.9,107.2,73.6,68.4,30.3,29.1,26.0,14.5 ; v_{\max }$ (film) 2941, 1668, $1565,1406,1231,1028 \mathrm{~cm}^{-1}$; HMRS (El) calcd for $\mathrm{C}_{11} \mathrm{H}_{14} \mathrm{O}_{3}[\mathrm{M}]^{+} 194.0943$, found 194.0938 .

1-(2-Methyl-5-tetrahydropyranyl-3-furanyl)-ethanone (15). $\mathrm{R}_{f}=0.20$ (pet. ether-EtOAc, 5:1); ${ }^{1} \mathrm{H}$ $\operatorname{NMR}\left(500 \mathrm{MHz} \mathrm{CDCl}_{3}\right) \delta 6.47(1 \mathrm{H}, \mathrm{s}, \mathrm{CH}$-furan), $4.33(1 \mathrm{H}, \mathrm{dd}, J=10.3,3.1 \mathrm{~Hz}, \mathrm{CHO}), 4.07(1 \mathrm{H}$, dddd, $\left.J=11.4,3.7,1.8,1.8 \mathrm{~Hz}, \mathrm{CH}_{2} \mathrm{O}\right), 3.59\left(1 \mathrm{H}, \mathrm{ddd}, J=11.4,11.4,2.3 \mathrm{~Hz}, \mathrm{CH}_{2} \mathrm{O}\right), 2.56(3 \mathrm{H}, \mathrm{s}$, $\left.\mathrm{CH}_{3} \mathrm{C}\right)$, $2.37\left(3 \mathrm{H}, \mathrm{s}, \mathrm{CH}_{3} \mathrm{C}=\mathrm{O}\right), 1.97-1.93\left(1 \mathrm{H}, \mathrm{m}, \mathrm{CH}_{2} \mathrm{CH}_{2} \mathrm{CH}_{2} \mathrm{O}\right)$, 1.87-1.76 (2H, m, $\left.\mathrm{CH}_{2} \mathrm{CHO}\right), 1.69-$ $1.55\left(3 \mathrm{H}, \mathrm{m}, \mathrm{CH}_{2} \mathrm{CH}_{2} \mathrm{O}, \mathrm{CH}_{2} \mathrm{CH}_{2} \mathrm{CH}_{2} \mathrm{O}\right) ;{ }^{13} \mathrm{C} \mathrm{NMR}\left(126 \mathrm{MHz} \mathrm{CDCl}_{3}\right) \delta 194.3,158.2,153.2,121.9$, 107.0, 72.8, 68.9, 29.6, 29.3, 25.8, 23.3, 14.6; $v_{\max }$ (film) 2937, 1676, 1566, $1406 \mathrm{~cm}^{-1}$; HMRS (EI) calcd for $\mathrm{C}_{12} \mathrm{H}_{16} \mathrm{O}_{3}[\mathrm{M}]^{+}$208.1099, found 208.1103.

Dihydro-5-(4-acetyl-5-methyl-2-furanyl)-2(3H)-furanone (18). $\mathrm{R}_{f}=0.18$ (pet. ether-EtOAc, 1:1); m.p. $=63-65^{\circ} \mathrm{C} ;{ }^{1} \mathrm{H} N M R\left(400 \mathrm{MHz}, \mathrm{CDCl}_{3}\right) \delta 6.63(1 \mathrm{H}, \mathrm{s}, \mathrm{CH}$-furan), $5.41(1 \mathrm{H}, \mathrm{t}, \mathrm{J}=7.2 \mathrm{~Hz}, \mathrm{CHO})$, 2.76-2.57 (2H, m, CH $\left.\mathrm{CH}_{2}\right), 2.56\left(3 \mathrm{H}, \mathrm{s}, \mathrm{CH}_{3} \mathrm{C}\right), 2.54-2.42\left(2 \mathrm{H}, \mathrm{m}, \mathrm{CH}_{2} \mathrm{CH}_{2}\right), 2.37\left(3 \mathrm{H}, \mathrm{s}, \mathrm{CH}_{3} \mathrm{C}=\mathrm{O}\right)$; ${ }^{13} \mathrm{C}$ NMR $\left(101 \mathrm{MHz} \mathrm{CDCl}_{3}\right) \delta 193.7,176.2,159.4,148.8,122.2,110.0,74.0,29.2,28.5,26.5,14.5$; $v_{\max }\left(\right.$ film) 1767, 1674, 1231, $1146 \mathrm{~cm}^{-1}$; HMRS (ESI) calcd for $\mathrm{C}_{11} \mathrm{H}_{12} \mathrm{NaO}_{4}[\mathrm{M}+\mathrm{Na}]^{+}$231.0628, found 231.0619 .

Tetrahydro-6-(4-acetyl-5-methyl-2-furanyl)-2H-pyran-2-one (19). $\mathrm{R}_{f}=0.27$ (pet. ether-EtOAc, $1: 1) ;{ }^{1} \mathrm{H}$ NMR (400 MHz, CDCl $) \delta 6.59(1 \mathrm{H}, \mathrm{s}, \mathrm{CH}$-furan), 5.31 (1H, dd, J = 9.6, $4.2 \mathrm{~Hz}, \mathrm{CHO}), 2.69-$ $2.50\left(2 \mathrm{H}, \mathrm{m}, \mathrm{CH}_{2} \mathrm{CO}\right), 2.56\left(3 \mathrm{H}, \mathrm{s}, \mathrm{CH}_{3} \mathrm{C}\right), 2.37\left(3 \mathrm{H}, \mathrm{s}, \mathrm{CH}_{3} \mathrm{C}=\mathrm{O}\right), 2.19-1.87\left(4 \mathrm{H}, \mathrm{m}, \mathrm{CH}_{2} \mathrm{CH}_{2} \mathrm{CHO}\right) ;{ }^{13} \mathrm{C}$ NMR $\left(126 \mathrm{MHz} \mathrm{CDCl}_{3}\right) \delta 193.8,170.3,158.9,149.6,122.1,108.9,74.6,29.6,29.2,26.2,18.4$, 14.5; $v_{\max }\left(\right.$ film) $1732,1674,1564 \mathrm{~cm}^{-1}$; HMRS (ESI) calcd for $\mathrm{C}_{12} \mathrm{H}_{14} \mathrm{O}_{4}[\mathrm{M}+\mathrm{Na}]^{+} 245.0784$, found 245.0781 . 
(17) General procedure for the cyclisation of secondary alcohols and aryl substrates such as 24-28 and 35-38: A solution of tetrahydrothiophene $\left(1.0 \mathrm{~mL}\right.$ of a $0.5 \mathrm{M}$ solution in $\left.\mathrm{CH}_{2} \mathrm{Cl}_{2}\right)$ was added to solution of the ynenedione $(1 \mathrm{mmol})$ and phenylphosphonic acid $(0.1 \mathrm{mmol})$ and the reaction mixture was stirred at $40^{\circ} \mathrm{C}$ for $48 \mathrm{~h}$. The mixture was then concentrated under reduced pressure and the residue purified by flash column chromatography on silica gel.

(18) Diastereomers were assigned by the use of two-dimensional nuclear Overhauser spectroscopy (NOESY) in order to establish the spatial relationship between the ring-junction protons of the tetrahydrofuran or tetrahydropyran. 